\title{
Wetland mitigation banking: Negotiations with stakeholders in a zone of ecological-economic viability
}

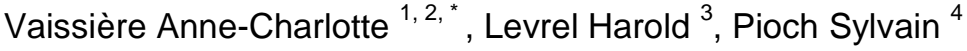

${ }^{1}$ Ecologie Systématique Evolution, CNRS, AgroParisTech, Université Paris-Sud, Université ParisSaclay, F-91400, Orsay, France

${ }^{2}$ AMURE, IFREMER, Université de Brest, CNRS, IUEM, ZI Pointe du Diable, CS 10070, F-29280, Plouzané, France

${ }^{3}$ CIRED, AgroParisTech, CIRAD, CNRS, EHESS, Ecole des Ponts ParisTech, Université de ParisSaclay, Campus du Jardin Tropical, 45 bis, Avenue de la Belle Gabrielle, F-94736, Nogent-sur-Marne, France

${ }^{4}$ CEFE, Université Paul-Valéry Montpellier 3, CNRS, Université Montpellier, EPHE, Route de Mende, F34199, Montpellier Cedex 5, France

* Corresponding author : Anne-Charlotte Vaissière, email address : anne.charlotte.vaissiere@gmail.com

\begin{abstract}
:
Wetland mitigation banking (WMB) is an organizational form that attempts to balance the ecological goals of wetland conservation and the economic goals of development with the aim of improving the implementation of wetland offsetting. Given the resulting tension, it is important to understand how the way stakeholders employ the WMB regulatory framework affects the goal of No Net Loss of wetlands. In this study, we interviewed WMB stakeholders in Florida in the United States to identify their strategies during negotiations around different aspects of defining wetland mitigation credits (e.g. service areas, types of credit and credit release schedules). Using the approach of New Institutional Economics, we found that within a framework of well-defined rules that nonetheless allow flexibility, WMB enables a field of action for negotiating within a zone of ecological-economic viability - in part due to the stakeholders' interest in maintaining a good reputation in this field. Outside of this zone of viability a wetland mitigation bank proposal collapses for economic or ecological reasons.
\end{abstract}

Keywords: Wetland offsetting, Wetland mitigation banking, Asset specificity, Environmental uncertainty, Stakeholders' strategy, Ecological-economic viability 


\section{Introduction}

In order to address biodiversity loss, today many countries legally require developers to follow a mitigation hierarchy that includes steps to first avoid, then reduce, and finally to offset impacts on biodiversity (e.g. wetlands or endangered species). Biodiversity offsetting, whose aim is to allow development such as urbanization and infrastructure projects while ensuring No Net Loss of biodiversity through the ecological restoration of equivalent degraded natural habitat elsewhere, is thus present in various policies and scientific agendas worldwide (Gonçalves et al., 2015; Levrel et al., 2015; Madsen et al., 2011; McKenney and Kiesecker, 2009). The term 'biodiversity offsetting' (or 'compensatory mitigation') encompasses actions designed to offset impacts on natural systems such as wetlands, streams or rivers, or on endangered species.

In the United States, the standard method of biodiversity offsetting is for a specific development project to compensate for its impact. Known as Permittee-Responsible Mitigation (PRM), this approach determines mitigation on a case-by-case basis. However, reports from American scientific organizations (National Research Council, 2001) and the US Government Accountability Office (Government Accountability Office, 2005) have highlighted that PRM has not been effective in terms of ecological and economic outcomes. These organizations also report high rates of non-compliance.

To improve the efficacy of biodiversity offsetting, the organizational approach of mitigation banking was developed nearly three decades ago. Initially devised for aquatic resources (Hough and Robertson, 2009), it has since been adapted for endangered species (conservation banking). The principle of mitigation/conservation banking relies on a third party that anticipates and pools the biodiversity offset needs of developers by restoring or enhancing natural areas on a large scale prior to any impact. These areas are called 'mitigation banks' when wetlands, streams or rivers are impacted, and 'conservation banks' when endangered species are impacted. The regulator (e.g. the responsible government and/or state agency) releases credits to the mitigation/conservation bank based on an assessment of the ecological gains achieved by the restoration project. When developers need to compensate for an impact, they then buy credits from the mitigation/conservation bank. This regulation system has been generally perceived as more effective for three main reasons: (1) the offsetting actions are carried out prior to any impacts; (2) the mitigation/conservation banks are easier for regulatory agencies to monitor since they concentrate offsetting for many development projects in a few sites; and (3) the larger size of the restored habitats results in better ecological performance. In this study, we focused specifically on wetland mitigation banking (WMB).

Compared to PRM, in which a development project implements its own offsets or hires a specialist to do so, WMB - in which a third party implements the offset - is often mistaken for a market (Vaissière 
et al., 2017; Levrel et al., 2017). In fact, it is more accurate to consider WMB as a highly regulated approach that includes market features (Vaissière and Levrel, 2015). Nonetheless, it is still valid to pose the question if the development of $\mathrm{WMB}$ as an alternative offsetting organizational form that has market characteristics might jeopardize the goal of No Net Loss of wetlands (BenDor et al., 2011; Calvet et al., 2015). The New Institutional Economics (NIE) theory provides certain useful concepts that could help investigate this question by redefining it in other terms.

Among other things, the NIE theory analyzes the performance of organizational forms by their capacity to minimize transaction costs ${ }^{1}$ (Coase, 1960; Williamson, 1985, 1996; Ménard and Shirley, 2014). In the case of $\mathrm{WMB}$, the question is whether this approach minimizes the costs of implementing wetland biodiversity offsetting (the 'transaction') compared to PRM. However, transaction costs are often difficult to assess directly (McCann et al., 2005). The NIE theory proposes that they can be assessed from three observable characteristics regarding the nature of the transaction: (1) its frequency (how often the transaction is repeated and how many stakeholder interactions it involves), (2) its uncertainty (the likelihood that the transaction will provide the expected results), and (3) its specificity (whether or not the specific knowledge and tools could be reused for another purpose). With regard to the WMB regulatory framework, it results in an increase in frequency (less agents responsible for the achievement of the offsets), a decrease in uncertainty (no temporal loss in wetlands as the ecological gain is already achieved when the impact occurs, and there is a better chance that a larger restored area will be conserved in the long term), and a decrease in specificity (a limited number of types of credits must cover the heterogeneity of wetlands) (Scemama and Levrel, 2014). More details are given in section 4.2. Theoretically, these evolved transaction characteristics lead to a decrease in transaction costs (Saussier and Yvrande-Billon, 2007) and support the decision of policymakers to employ WMB. However, the issue of a decrease in asset specificity is important to consider. In the context of wetland offsetting, asset specificity is linked to ecological equivalence between the impacted and the restored area (in terms of equivalence in the type of wetland ecosystem, its location, and the temporal scale for achieving an ecological response from a restoration action). Therefore, a core issue is the maintenance of a high level of asset specificity to achieve the goal of No Net Loss of wetlands (Scemama and Levrel, 2014). However, if asset specificity is too high, this could lead to wetland offsets that are usable only for specific impacts; this is not compatible with the principle of WMB, which requires pooling offsetting measures from different projects. This results in tension between the development of WMB and its ability to achieve No Net Loss of wetlands.

\footnotetext{
${ }^{1}$ Transaction costs are all the costs linked to the organization of a transaction (such as the time spent to define public policy and regulations) and must be differentiated from production costs, which are the expenses related to the achievement of a transaction (such as the cost of ecological restoration works).
} 
The NIE theory also emphasizes the importance of analyzing organizational forms as dynamic objects that evolve through feedback loops of, for example, involved stakeholders (Ménard, 2012). So it is valuable to understand how the numerous stakeholders in WMB manage these tensions in practice and employ the WMB regulatory framework, in turn influencing how the transaction characteristics evolve. Additionally, as the literature cited above points out, it is important that researchers pay particular attention to the potential decrease in asset specificity.

The research question in this study was to analyze the relevance of using WMB by examining what levers the stakeholders involved use in practice, and how they negotiate trade-offs regarding economic efficiency (the profitability of a transaction) and ecological efficacy (the objective of No Net Loss of wetlands). The NIE theory was chosen as a tool to help identify if the behavior of WMB stakeholders tends to stray away or remain close to the objective of wetland offsetting by looking at two elements in particular: the characteristics of the transaction and the dynamic features of the organizational form. This study thus adds to the small amount of existing NIE literature in the field of biodiversity conservation from authors that have recently selected this framework to analyze biodiversity offsetting (Coggan, 2013a, 2013b, 2013c; Scemama and Levrel, 2014; Lapeyre et al., 2015; Vaissière and Levrel, 2015). We chose to study WMB in Florida, where a large surface area of wetlands has been destroyed over the last decades (Robertson, 2004; Robertson and Hayden, 2008; Hough and Robertson, 2009; Reiss et al., 2009; BenDor and Riggsbee, 2011), and which is also one of the first places in the world where WMB emerged three decades ago. We hope this study will contribute to helping policymakers in other countries to better anticipate the introduction of such innovative tools and to avoid stakeholders straying from the No Net Loss goal.

\section{Materials and methods}

With 11.4 million acres of wetlands and a relative wetland density of $20-35 \%$ of its total land area, Florida is one of the densest wetland regions in the United States (BenDor et al., 2011). In 2013, more of its surface area was covered by wetland mitigation banks (nearly 190,000 acres ${ }^{2}$ ) than in any other US state. For this field study on WMB, we visited 20 wetland mitigation banks around Florida and conducted 54 face-to-face semi-structured interviews in 2013. Each interview lasted half a day. Of the 54 individuals interviewed, 20 were environmental consultants, 28 were involved in a mitigation bank project, 7 worked for a regulatory agency, 4 were brokers, and 6 practiced other professions (e.g. lawyers, academics, NGO member/employees, developers/clients of a mitigation bank). Some individuals combined several roles: for instance, an environmental consultant might be hired as a wetland mitigation bank manager. The interviews gathered information on 71 out of the 91 approved or pending Florida wetland mitigation banks at the time the fieldwork was conducted (at the time of

\footnotetext{
${ }^{2}$ RIBITS (Regulatory In-lieu fee and Bank Information Tracking System) database: https://ribits.usace.army.mil/ribits apex/f?p=107:2 (accessed March 2013)
} 
the study, there were about 1800 wetland mitigation banks in the United States). Of the 71 wetland mitigation banks studied, 58 were private commercial (i.e. the third party investing in the wetland mitigation bank was a private individual). The average surface area of a wetland mitigation bank in Florida is $8 \mathrm{~km}^{2}$ (ranging from $0.2 \mathrm{~km}^{2}$ to $98 \mathrm{~km}^{2}$ ).

We asked the people interviewed to describe how WMB in Florida is supposed to work in theory, as well as to share their experience on how this organizational form functions in reality. We then analyzed this information using NIE theory, which was valuable in identifying the key elements on which the efficiency of the system relies.

\section{What is wetland mitigation banking?}

\subsection{An overview}

A wetland mitigation bank is a physical area where wetland restoration actions are carried out. It also refers to the juridical entity that receives wetland mitigation credits, whose type and quantity respectively correspond to the type of wetland to be restored and to the ecological improvements obtained from the restoration action. Developers then buy these credits as required to offset the impact of their development project. At least two rules regulate the sale/purchase of wetland mitigation credits. First, a wetland mitigation bank cannot sell all its credits at the outset of its creation; the regulators release the credits to be sold over time, following a credit release schedule whose steps are based on administrative and ecological performance criteria. Second, a wetland mitigation bank can sell its credits only inside its service area: this is a physical area that usually corresponds to the river basin where the bank is located. The challenge for a wetland mitigation bank is to be both economically and ecologically viable - in other words, the bank must generate measurable ecological gains that can be used to offset impacts, while also being profitable for investors in this new sector.

\subsection{The rules of wetland mitigation banking that govern negotiations}

The 2008 Final Compensatory Rule (US Army Corps of Engineers and US Environmental Protection Agency, 2008) outlined a regulatory framework for wetland offsetting with detailed rules for WMB. This resulted in reducing uncertainty regarding ecological and economic goals for three main reasons (Scemama and Levrel, 2014). Firstly, it secured the perpetual existence of wetland mitigation banks through conservation easements that limit for perpetuity any human use that could generate an impact on the bank, and by requiring each bank to have a long-term management plan and financial guarantees. Secondly, it helped to prevent potential opportunistic behavior of wetland mitigation banks by transferring responsibility for the success of the offset from the developer to the wetland mitigation bank, via a credit release schedule based on means and ecological results that allow the release and selling of credits to be frozen if a wetland mitigation bank voluntarily does not meet its commitments. 
Thirdly, it gave incentives for stakeholders to participate in WMB: these include a regulatory preference for WMB over PRM by government agencies, high restoration performance requirements that attract specialists trained in ecological restoration, and the creation of a new profitable industry. Regulators also locally co-constructed ecological equivalence assessment methods for calculating wetland mitigation credits; these methods are used to assess both the losses at the impacted area and the gains at the wetland mitigation bank. In Florida, the Uniform Mitigation Assessment Method ${ }^{3}$ is the standard. This method is based on ecological functions categorized in three groups - Location and Landscape Support, Water Environment, and Community Structure (including flora and fauna)rather than on surface area. It takes into account uncertainty in restoration success and the time lag between restoration and its effective results.

\section{Results}

\subsection{The stakeholders and their motivations}

WMB allows an impact to be compensated through a limited number of types of credits (which are supposed to represent the heterogeneity of wetlands) that can be exchanged within a defined service area rather than in the exact location of the impact. This has the result of reducing the asset specificity (Scemama and Levrel, 2014). In this system, the composition of damaged and restored wetlands will not be exactly alike in terms of fauna and flora (e.g. Stefanik and Mitsch, 2012) or, even more generally, in terms of ecological function ${ }^{4}$. Furthermore, the restored wetland may not be near the impacted wetland, despite the fact that the distance (Quétier and Lavorel, 2011) or the exact location on a river basin (Reiss et al., 2014) can have an influence on ecological equivalence. Nonetheless, the regulatory framework described in section 3.2 includes rules that limit this decrease in specificity to an 'ecologically acceptable' level - i.e. a level of ecological equivalence that remains feasible and has the maximum chance of being reached. From an NIE perspective, asset specificity can be divided into several subtypes, including physical specificity (the physical nature of the asset in more or less detail) and site specificity (the spatial nature of the asset in more or less detail). In the case of WMB, physical specificity is addressed by including several different types of credits that correspond to the main types of Florida wetlands, and site specificity is addressed by usually requiring the service area to match the river basin where the wetland mitigation bank is located.

Regardless of these rules limiting the decrease in asset specificity, some flexibility in WMB is necessary because the system must be adaptive in order to deal with the complexity of living things, which is difficult to fully anticipate. For instance, it can be difficult to classify certain wetlands within

\footnotetext{
${ }^{3}$ UMAM, http://www.dep.state.fl.us/water/wetlands/mitigation/umam/index.htm (accessed June 2016)

${ }^{4}$ In fact, one might consider that the very principle of biodiversity offsetting reduces specificity because of the uniqueness of ecosystems.
} 
one of the WMB credit types. Consequently, in practice, the WMB approach cannot be too rigid, and stakeholders must make adjustments in a process of negotiation. The different stakeholders come to the table with different motivations. Figure 1 illustrates the principal stakeholders in a wetland mitigation bank.
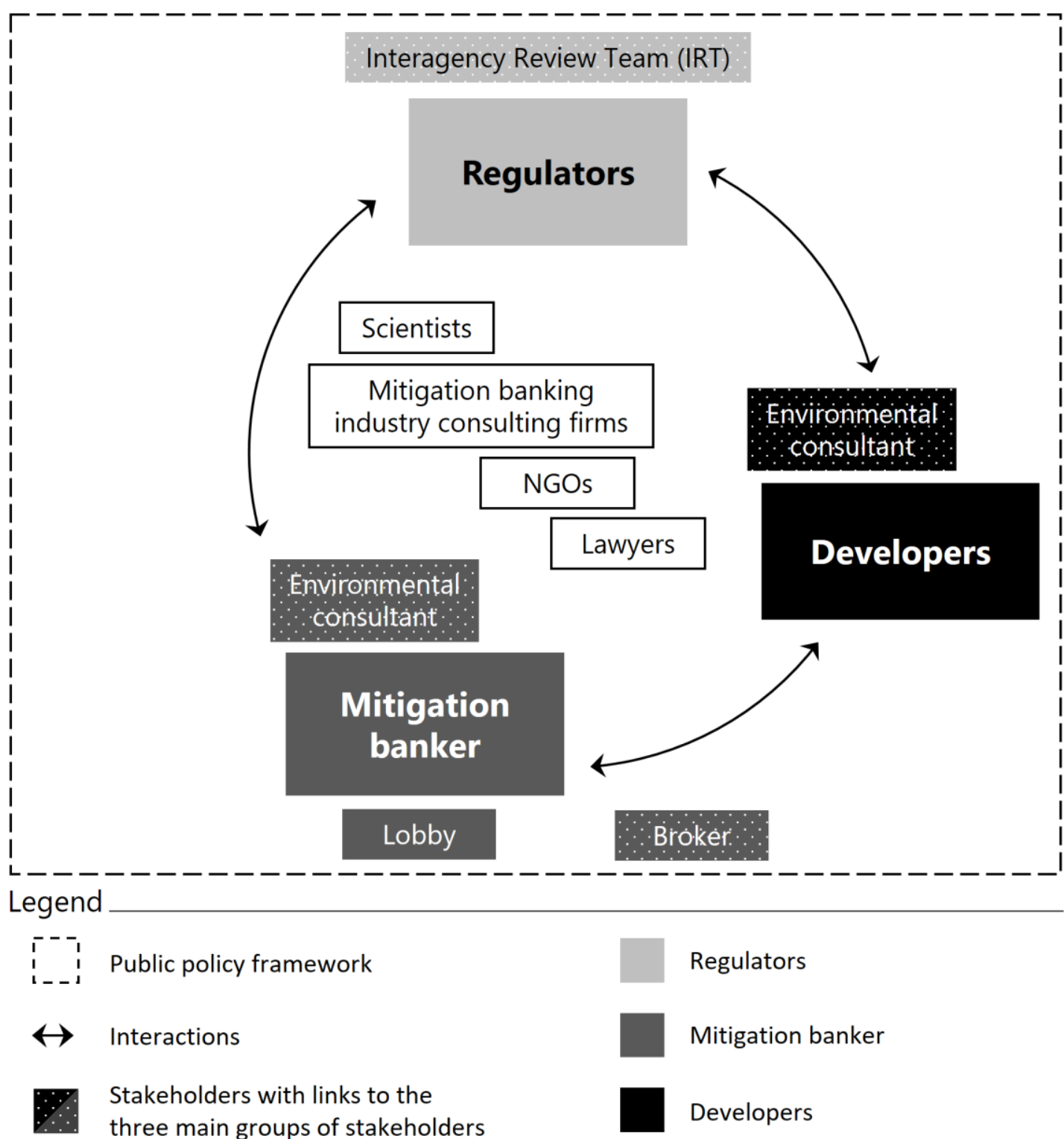

Public policy framework

Regulators

Interactions

Mitigation banker

Stakeholders with links to the

three main groups of stakeholders

Developers

Independent stakeholders

Figure 1: The stakeholders in a wetland mitigation bank

In Florida, most wetland mitigation bankers are private organizations whose main goal is to make a profit ${ }^{5}$. In return, they take financial risks since a wetland mitigation bank project requires significant upfront costs, and the return on investment may take several years (Robertson and Hayden, 2008; BenDor et al., 2011). The goal of the developer is generally to fulfill the regulatory requirements for mitigation at the lowest cost. The goal of the regulator is to enforce the environmental principle of No

\footnotetext{
${ }^{5}$ There are also public mitigation bankers, but they must respect a non-profit rule.
} 
Net Loss of wetlands while ensuring that the wetland mitigation bank is operational and profitable (under pressure from the WMB private lobby). There are two types of regulatory agencies: those that issue wetland mitigation bank permits and those that issue building/development permits (and oversee PRM proposals). Other stakeholders are also involved in making WMB work. An Interagency Review Team (IRT) is created for each wetland mitigation bank to ensure that all the environmental and cultural issues are considered. Environmental consultants are hired either by wetland mitigation bankers or by developers and work closely with regulators. A broker may help in bringing together the developer and wetland mitigation banker to decide on a price for the credits. NGOs, lawyers, scientists and/or mitigation banking industry consulting firms may also be involved.

\subsection{Wetland mitigation banking in practice: the stakeholders' negotiation objectives}

Figure 2 shows the stakeholders and the topics that must be negotiated. Table 1 summarizes the negotation objectives of each of the three main stakeholders and the transaction characteristics affected by each topic of negotiation. 


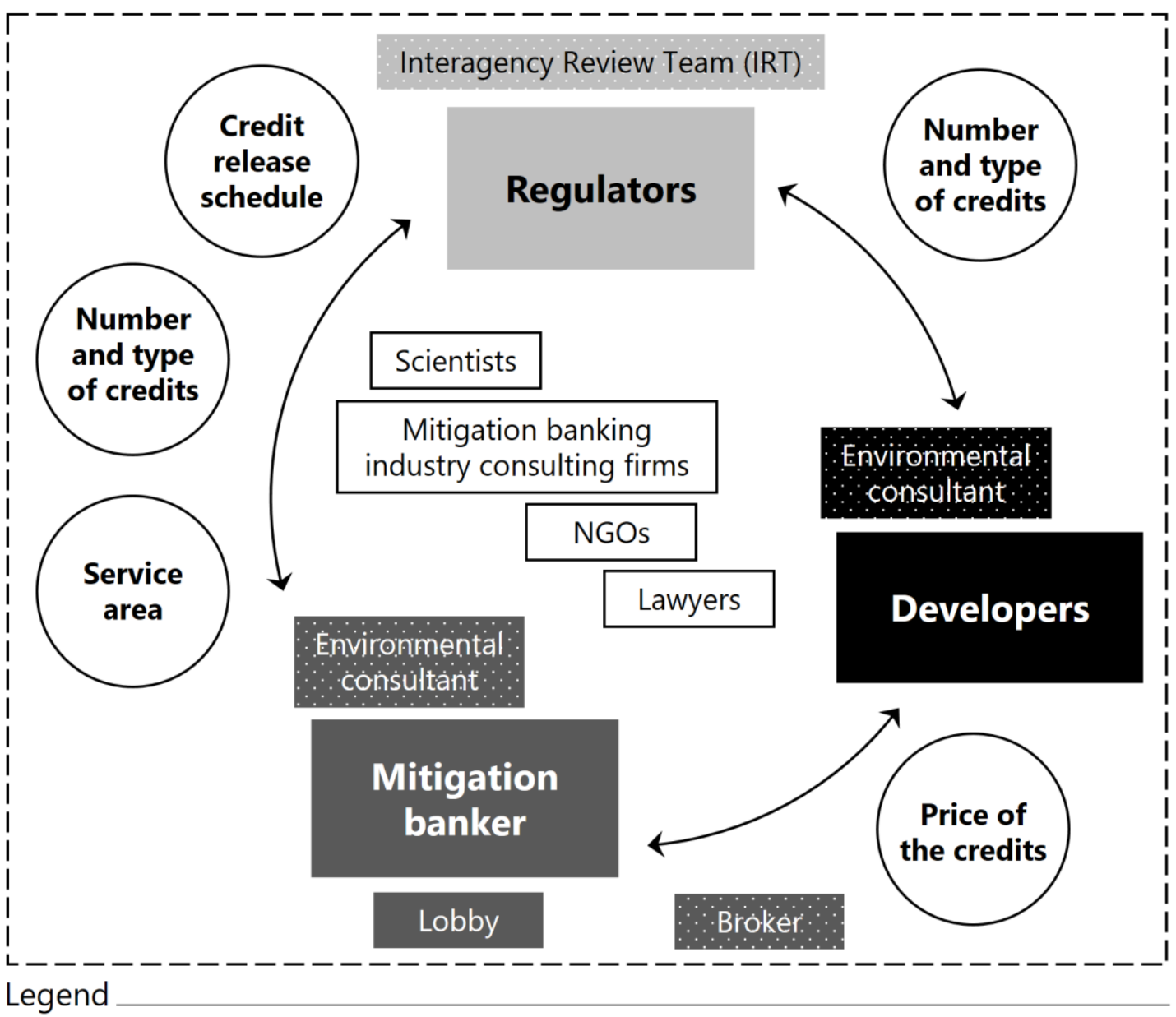

$i_{--1}$ Public policy framework

Regulators

$\leftrightarrow \quad$ Interactions

Mitigation banker

Stakeholders with links to the three main groups of stakeholders

Developers

Topic of negotiation

Independent stakeholders

Figure 2: The topics of negotiation by stakeholders in a wetland mitigation bank 
Table 1 - Topics of negotiation (and the transaction characteristics affected) and stakeholders' objectives

\begin{tabular}{|c|c|c|c|}
\hline $\begin{array}{c}\text { Segotiation topics } \\
\text { (transaction characteristic } \\
\text { affected })\end{array}$ & $\begin{array}{c}\text { Wetland mitigation } \\
\text { banker }\end{array}$ & Developer & Regulator \\
\hline $\begin{array}{c}\text { Service area } \\
\text { (Site specificity) }\end{array}$ & Extended service area & NA & $\begin{array}{c}\text { Suitably restricted } \\
\text { service area }\end{array}$ \\
\hline $\begin{array}{c}\text { Type of credits } \\
\text { (Environmental } \\
\text { uncertainty) }\end{array}$ & $\begin{array}{c}\text { Credits that have a high } \\
\text { price or are in demand in } \\
\text { the service area }\end{array}$ & $\begin{array}{c}\text { Credits that have a low } \\
\text { price or are easily } \\
\text { available in the area of } \\
\text { impact }\end{array}$ & $\begin{array}{c}\text { Credits that best } \\
\text { correspond to the } \\
\text { ecological gain or loss }\end{array}$ \\
\hline $\begin{array}{c}\text { Number of credits } \\
\text { (Environmental } \\
\text { uncertainty) }\end{array}$ & $\begin{array}{c}\text { Release of numerous } \\
\text { credits }\end{array}$ & $\begin{array}{c}\text { Requirement to buy few } \\
\text { credits }\end{array}$ & $\begin{array}{c}\text { Release of an adequate } \\
\text { number of credits }\end{array}$ \\
\hline $\begin{array}{c}\text { Credit release schedule } \\
\text { (Environmental } \\
\text { uncertainty) }\end{array}$ & $\begin{array}{c}\text { Authorization of early } \\
\text { release of credits }\end{array}$ & NA & $\begin{array}{c}\text { Release of credits after } \\
\text { the ecological lift is } \\
\text { effective }\end{array}$ \\
\hline
\end{tabular}

The extent of the service area is a strategic stake for wetland mitigation bankers since this determines the size of the market for their credits (Vaissière and Levrel, 2015). As a result, where possible, they will try to extend the service area. For instance, if a wetland mitigation bank is located between two subbasins, the wetland mitigation banker would try to include both in its service area. However, if the service area is too extensive, the location of the restored wetlands may be too far from the impacted wetlands. To address this, regulators try to maintain a service area that has an ecological meaning. Negotiations around the topic of the service area mainly influence the issue of site specificity. In the United States, a service area usually corresponds to the watershed identified by the 8-digit hydrological unit code given by the US Geological Survey. This corresponds to an average of $1800 \mathrm{~km}^{2}$ (Seaber et al., 1987); however, in Florida, the average service area is around $3800 \mathrm{~km}^{2}$ (Levrel et al., 2017).

The type of credits is a strategic stake because these credits represent the service that wetland mitigation bankers sell to developers, and that developers buy from wetland mitigation bankers (Vaissière and Levrel, 2015). The different types of credits defined to cover the whole range of wetlands are not exchanged at the same price, as this depends on their scarcity and their potential demand in a given area. In Florida, there are 8 types of wetland credits (RIBITS), including freshwater credits (palustrine, palustrine emergent, palustrine forested, palustrine scrub/shrub, palustrine open water) and estuarine/coastal credits (estuarine, estuarine intertidal emergent, estuarine intertidal forested). For instance, estuarine credits are more expensive (up to USD 200,000), so wetland mitigation bankers would benefit from having their credits labelled as estuarine credits, even if the estuarine nature of the bank is questionable (conversely, the opposite is true for the developer and the associated loss due to the impacts of the project). Therefore, wetland mitigation bankers may try to maximize their revenue by having their ecological lift translated to credits that have a high price or are 
in demand in the service area. In contrast, a developer may try to minimize cost by making the ecological loss due to impacts translated to credits that have a low price or are easily available in the area of impact. The problem is that if the type of credit is not equivalent to the real nature of the ecological loss or gain, this can potentially result in poor qualitative equivalence ${ }^{6}$. Regulators thus push the ecological stakes in negotiations, to favor credits that best identify the ecological lift. This leads to good qualitative equivalence, but runs the risk of generating poor returns for wetland mitigation bankers - for example, if the type of credits defined have a low price (conversely, the opposite is true for developers). These negotiations mainly affect environmental uncertainty ${ }^{7}$, which is a type of external uncertainty. Environmental uncertainty is defined as all the consequences of ecological dynamics that are difficult to forecast or manage, such as extreme natural events or uncontrollable exotic species invasion; within the context of wetland offsetting, environmental uncertainty would be the likelihood of reaching (or not) the goal of No Net Loss of wetlands. In the negotiations around the type of credits, the degree of similarity between the impacted and the restored wetland is influenced.

The number of credits is a critical source of revenue for wetland mitigation bankers, but a critical expense item for developers. It is determined using specific assessment methods based on expert analysis and is regularly discussed during the permitting phase between the wetland mitigation banker's or the developer's environmental consultant and the members of the Interagency Review Team (IRT). Wetland mitigation bankers may try to push the negotiations toward the release of numerous credits to have a maximum number to sell, while developers will try to restrict the amount of credits they are required to purchase to decrease their expenses. These negotiations may lead to a net loss of wetlands in some cases. In reality, as it is impossible to anticipate the exact change over time of wetlands, at a later point wetland mitigation bankers can ask the regulators to receive more credits than the amount decided during the permitting process if the ecological results of the wetland mitigation bank are better than expected: this is called a realignment of the number of credits. The regulators' objective is to push these negotiations toward the release of an adequate number of credits to wetland mitigation bankers, and the request for an adequate number of credits to be purchased by the developer. This should lead to No Net Loss of wetlands, but with a potentially less attractive economic situation for wetland mitigation bankers and developers. These negotiations mainly affect the transaction's environmental uncertainty in maintaining a balance between the ecological lift

\footnotetext{
${ }^{6}$ Another case, not discussed in our study, is that some wetland mitigation bankers may choose ecological restoration actions to create wetlands for which credits are more expensive, even if this is not necessarily consistent with the nature of the land where the wetland mitigation bank is created. In cases such as this, the role of the regulator is to identify and prevent these projects.

${ }^{7}$ Outside of the negotiations that take place at the scale of a wetland mitigation bank, there are equally negotiations that take place at the public policy level (often with the WMB lobby) regarding the list of the types of credits. These influence physical specificity.
} 
provided by a certain amount of credits and the ecological loss due to the impact. It is difficult to estimate the mean number of credits released per wetland mitigation bank since this number relies on the initial conservation status of the land and on the type of restoration measures carried out.

On the topic of the credit release schedule, the first share of credits is released when the means ${ }^{8}$ for ecological restoration has been implemented. This risks the potential temporal loss of ecological function for reasons of economic feasibility (i.e. when credits are released for the completion of administrative steps). Wetland mitigation bankers may push the negotiations toward an early release of credits in order to obtain revenue more quickly, while regulators typically favor the release of credits after the ecological lift is effective in order to avoid a temporal loss of wetlands. The risk is that this jeopardizes the viability of the business model of the wetland mitigaiton bank. Negotiations on this topic mainly affect environmental uncertainty (the temporal aspect of No Net Loss). In Florida, on average, $26 \%$ of credits are released for achieving administrative steps, $37 \%$ are released for creation and planting steps, and the remaining $37 \%$ are released based on ecological success (measured by predetermined criteria). All the credits are released over a period of about nine years (data collected from wetland mitigation bank ledgers on the RIBITS website). At the national scale, the share of administrative credits ranges from 15 to $60 \%$, with an average of $36.7 \%$ (BenDor et al., 2011).

The only negotiation that does not involve a trade-off between ecological and economic stakes is the negotiation of the price of credits between developers and wetland mitigation bankers (with the help of brokers), because regulators approve in advance the number and type of credits that the developers have to buy. In Florida, the price ranges from USD 25,000 to 200,000 per credit, with the mean surface involved in 'producing' one credit being $13,000 \mathrm{~m}^{2}$.

So considering WMB in practice, once the general rules are set, the negotiations between stakeholders mostly influence environmental uncertainty, apart from those concerning the service area, which influences site specificity.

\section{Discussion}

\subsection{Maintaining a good reputation moderates the negotiations}

WMB leads to more interactions between a limited number of stakeholders responsible for the success of compensatory measures (i.e. an increased frequency of transactions). This gives regulators more monitoring control, and also means they know the wetland mitigation bankers from working with them often. This has the effect of encouraging WMB stakeholders to remain moderate during

\footnotetext{
${ }^{8}$ These 'means' can include meeting the administrative requirements or the physical steps required to create the project. The remainder of the credits are released when ecological results are achieved.
} 
negotiations to maintain their reputation and relationships. For instance, if a wetland mitigation banker were to make dishonest or unrealistic claims regarding a wetland mitigation bank, in case of failure the banker would be penalized by regulators for noncompliance and may be banned from making future proposals. It is therefore in the interest of wetland mitigation bankers to ensure ecologically viable projects that will receive approval and to avoid having unreleased or unsellable credits. The same is true for developers seeking permit approval for a project. On their part, regulators seek to meet the objective of No Net Loss of wetlands with the understanding that if their requirements are too demanding, this risks making the project economically unviable. To facilitate these discussions, the environmental consultant plays a key role, balancing ecological and economic stakes during permitting negotiations. The reputation of the environmental consultants, and hence their chance to work on future projects, depends on their ability to negotiate a satisfactory level of credits for the wetland mitigation banker as well as a good level of ecological performance. A successful result is the approval of a wetland mitigation bank (the banker's interest) that is of good environmental quality (the regulatory agency's interest). This is true for environmental consultants hired by any of the stakeholders - bankers or developers.

\subsection{Ecological-economic viability in wetland mitigation banking}

Our findings indicate that there is no single definite rule for establishing a wetland mitigation bank; rather WMB seems to be able to adapt to complexity by allowing negotiations (within a framework of rules), which are partly influenced by each stakeholder's interest in maintaining a good reputation, as described in section 5.1. A key finding from our fieldwork is that negotiations seem to be carried out in a zone of viability - outside of this zone a wetland mitigation bank proposal collapses for economic or ecological reasons (Figure 3).

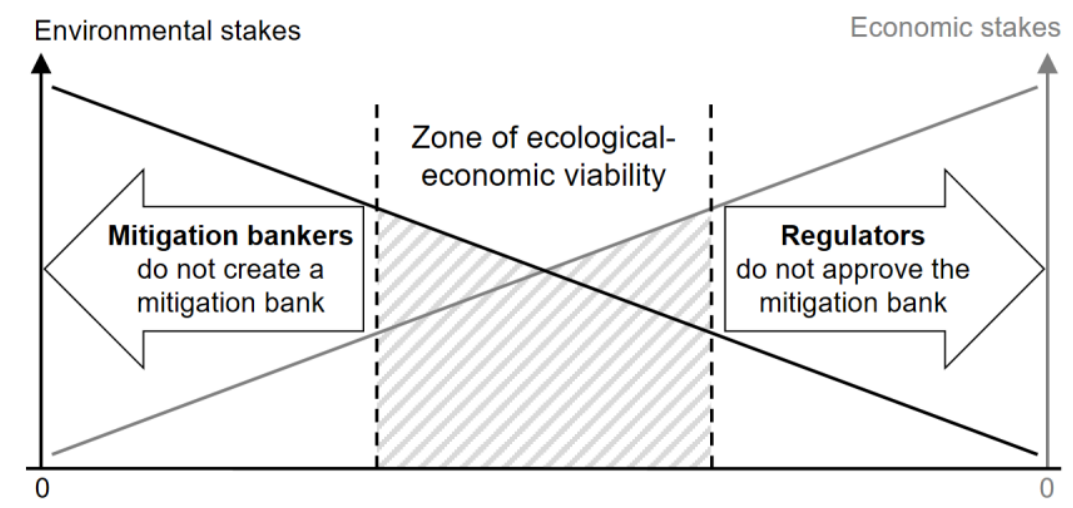

Figure 3: Zone of viability for the existence of a wetland mitigation bank

Site specificity and environmental uncertainty, which are the transaction characteristics influenced during the negotiations (Table 1), are thus kept to acceptable levels within this viability zone. For the former, it is important that the negotiated level of site specificity retains ecological meaning while 
allowing a market within which credits can be sold. For the latter, the very principle of WMB leads to a decrease in environmental uncertainty; our findings show that negotiations maintain this reduced environmental uncertainty while allowing a viable business model for wetland mitigation banks. These outcomes compare favorably to those resulting from PRMs, which although in principle are adapted to an impact since they are designed for this specific purpose, often fail in practice for organizational reasons. The innovation of WMB allows for fewer but larger restoration areas to be created in advance, making them more effective and easier to control and giving them a better chance to be maintained in the long term. They can also be integrated in more ambitious conservation projects. While PRM and WMB can be complementary in some cases (for example, PRM is preferable for impacts affecting wetlands for which no credits are available or that need to be compensated at close proximity), WMB may improve the ecological performance of wetland offsetting.

\section{Conclusion}

The challenge for WMB is that it must perform a balancing act between ecological and economic goals. In the development of WMB, compared to PRM, regulators have been able to create the conditions that allow an increase in the frequency of transactions and a decrease in the uncertainty surrounding these transactions. To achieve this, asset specificity can be weakened - WMB attempts to limit this through restricted types of credits and the principle of service areas. All these evolutions decrease transaction costs. However, the risk is that decreased asset specificity, if not properly supervised, could lead to the reduced complexity of wetlands and move away from the goal of No Net Loss of wetlands. This is why it is essential to analyze how stakeholders use the WMB organizational form, in particular when negotiating the conditions of the different aspects of wetland mitigation credits: spatial (service area), quantitative (number of credits), qualitative (type of credits), and temporal (credit release schedule). As the rules allow flexibility to make WMB feasible, regulators are able to discuss and interpret the law to manage the tension that exists between economic and ecological stakes.

Our findings from the Florida case study show that more than reducing asset specificity, WMB negotiations - compared to PRM - tend to mainly influence site specificity ${ }^{9}$ and environmental uncertainty. Wetland mitigation bankers and developers may tend to decrease the site specificity and to increase environmental uncertainty by pushing negotiations toward more economic stakes that weaken the likelihood of No Net Loss of wetlands. Regulators take the opposite position in the negotiations. Yet the managed flexibility of WMB and the stakeholders' desire to maintain their reputation results in an ecological-economic zone of viability in which it is in all parties' interest to find common ground; outside of this zone of viability the wetland mitigation bank is not approved.

\footnotetext{
${ }^{9}$ Negotiations that influence the physical specificity tend to take place at the public policy level; this is where the number of types of credits is decided.
} 
Environmental consultants play a key role in this system to mediate between regulators, wetland mitigation bankers and developers.

While US policymakers have neither eradicated all possible misuses of WMB nor found the solution to reach No Net Loss of wetlands, they have made real efforts to create the conditions for improving the implementation of wetland offsetting. WMB seems to have potential, provided it is well regulated and its market characteristics are contained. The current form of WMB in Florida is the result of some 30 years of development through feedback loops affected by stakeholder behavior (Vaissière and Levrel, 2015). This makes the approach quite advanced and stable, while allowing negotiation flexibility so it can continuously adapt to the case in question. We suggest that using the framework of WMB to try to meet the objective of No Net Loss is a pragmatic, socially constructed response to address the need of economic development.

\section{Acknowledgements}

We would like to thank the University of Western Brittany (Université de Bretagne Occidentale) and the Europôle Mer research consortium, which financed the fieldwork in Florida, as well as the IFREMER Marine Economics Unit and the regional government of Brittany for providing support for this study. We are also grateful to the Nova Southeastern University Oceanographic Center, which hosted our stay in Florida; we thank them for their warm welcome and collaboration. This study was made possible by interviews with mitigation/conservation bank stakeholders in Florida - we are very thankful for their time and availability to answer our questions. 


\section{References}

BenDor, T.K., Riggsbee, J.A. (2011). Regulatory and ecological risk under federal requirements for compensatory wetland and stream mitigation. Environmental Science \& Policy 14(6): 639-649.

BenDor, T.K., J.A. Riggsbee, J.A., Doyle, M. (2011). Risk and markets for ecosystem services. Environmental Science \& Technology 45(24): 10322-10330.

Calvet, C., Napoléone, C., Salles, J.M. (2015). The biodiversity offsetting dilemma: between economic rationales and ecological dynamics. Sustainability 7: 7357-7378.

Coase, R.H. (1960). The problem of social cost. Journal of Law and Economics, 3: 1-44.

Coggan, A., Buitelaar, E., Whitten, S.M. (2013a). Transferable mitigation of development impacts. The case of development offsets at Mission Beach, Australia. Journal of Environmental Policy and Planning, 15(2): 303-322.

Coggan, A., Buitelaar, E., Whitten, S.M., Bennett, J. (2013b). Factors that influence transaction costs in development offsets: who bears what and why? Ecological Economics, 88: 222-231.

Coggan, A., Buitelaar, E., Whitten, S.M., Bennett, J. (2013c). Intermediaries in environmental offset markets: Actions and Incentives. Land Use Policy, 32(1): 145-154.

GAO (Government Accountability Office) (2005). Wetlands protection. Corps of engineers does not have an effective oversight approach to ensure that compensatory mitigation is occurring. Government Accountability Office.

Gonçalves, B., Marques, A., Velho Da Maia Soares, M.A., Pereira, H.M. (2015). Biodiversity Offsets: From Current Challenges to Harmonized Metrics. Current Opinion in Environmental Sustainability 14. Open Issue (June): 61-67.

Hough, P., Robertson, M. (2009). Mitigation under section 404 of the clean water act: where it comes from, what it means. Wetlands Ecology and Management 17(1): 15-33.

Lapeyre, R., Froger, G., Hrabanski, M. (2015). Biodiversity offsets as market-based instruments for ecosystem services? From discourses to practices. Ecosystem Services 15: 125-133.

Levrel H., Frascaria N., Hay J., Martin G., Pioch S. (eds.) (2015). Restaurer la nature pour atténuer les impacts du développement. Analyse des mesures compensatoires pour la biodiversité, Collection Synthèses, Editions Quae, 320p.

Levrel, H., Scemama, P., Vaissière, A.C. (2017). Should we be wary of mitigation banking? Evidence regarding the risks associated with this wetland offset arrangement in Florida. Ecological Economics 135: 136-149.

Madsen, B., Carrol, N., Kandy, D., Bennett, G. (2011). 2011 Update. State of biodiversity markets report: offset and compensation programs worldwide. Washington: Ecosystem Marketplace, $73 \mathrm{p}$.

McCann, L., Colby, B., Easter, K. W., Kasterine, A., Kuperan, K.V. (2005). Transaction cost measurement for evaluating environmental policies. Ecological Economics, 52: 527-542.

McKenney, B.A., Kiesecker, J.M. (2009). Policy development for biodiversity offsets: a review of offset frameworks. Environmental Management, 45(1): 165-176.

Ménard, C. (2012). L’économie des organisations. Paris: La Découverte, 128 p.

Ménard, C., Shirley, M.M. (2014). The Future of New Institutional Economics: From Early Intuitions to a New Paradigm? Journal of institutional economics, 10: 541-565. 
NRC (National Research Council) (2001). Compensating for wetland losses under the Clean Water Act. Washington DC: National Academy Press.

Quétier, F., Lavorel, S. (2011). Assessing ecological equivalence in biodiversity offset schemes: key issues and solutions. Biological Conservation 144(12): 2991-2999.

Reiss, K.C., Hernandez, E., Brown, M.T. (2009). Evaluation of permit success in wetland mitigation banking: a florida case study. Wetlands 29(3): 907-918.

Reiss, K.C., Hernandez, E., Brown, M.T. (2014). Application of the landscape development intensity LDI) index in wetland mitigation banking. Ecological Modelling 271: 83-89.

Robertson, M. (2004). The neoliberalization of ecosystem services: wetland mitigation banking and problems in environmental governance. Geoforum 35(3): 361-373.

Robertson, M., Hayden, N. (2008). Evaluation of a market in wetland credits: entrepreneurial wetland banking in chicago. Conservation Biology 22(3): 636-646.

Saussier, S., Yvrande-Billon, A., 2007. Economie des Coûts de Transaction. La Découverte, Paris.

Scemama, P., Levrel, H. (2014). L'émergence du marché de la compensation des zones humides aux États-Unis : impacts sur les modes d'organisation et les caractéristiques des transactions. Revue d'Economie Politique 123(6): 893-924.

Seaber, P.R., Kapinos, F.P., Knapp, G.L. (1987). Hydrologic Unit Maps: U.S. Geological Survey. Washington, DC: U.S. Geological Survey, 20 p.

Stefanik, K.C., Mitsch, W.J. (2012). Structural and functional vegetation development in created and restored wetland MBs of different ages. Ecological Engineering 39: 104-112.

US Army Corps of Engineers, US Environmental Protection Agency (2008). Compensatory mitigation for losses of aquatic resources; Final Rule. In: Federal Register, 73 Fed. Reg. 70, pp. 19593-19705.

Vaissière, A.C., Levrel, H. (2015). Biodiversity offset markets: What are they really? An empirical approach to wetland mitigation banking. Ecological Economics 110, 81-88.

Vaissière, A.C., Levrel, H., Scemama, P. (2017). Biodiversity offsetting: clearing up misunderstandings between conservation and economics to take further action. Biological Conservation 206: 258-262.

Williamson, O.E. (1985). The economic institutions of capitalism: firms, markets, relational contracting. New York: The Free Press Macmillan.

Williamson, O.E. (1996). The Mechanisms of Governance, Oxford: Oxford University Press. 